\title{
Gastric adenocarcinoma with rhabdoid morphology
}

\author{
Kohei Shomori $\cdot$ Kenji Sugamura $\cdot$ Kaori Adachi $\cdot$ \\ Tatsushi Shiomi $\cdot$ Eiji Nanba $\cdot$ Hisao Ito
}

Received: 2 August 2010/ Accepted: 13 February 2011/Published online: 17 March 2011

(C) The International Gastric Cancer Association and The Japanese Gastric Cancer Association 2011

\begin{abstract}
Extrarenal rhabdoid tumors (ERRTs) are very rare neoplasms and have been reported in a range of organs, including sixteen cases in the stomach. We describe a woman aged 86 years who had an advanced gastric tumor with lymph node metastasis. The tumor mostly showed a diffuse arrangement with a small glandular region. The tumor cells were non-cohesive and had polygonal morphology with eccentric vesicular nuclei, prominent nucleoli, and abundant eosinophilic cytoplasm, i.e. they showed rhabdoid features. Immunohistochemically, the rhabdoid tumor cells were strongly positive for cytokeratins and vimentin. However, a candidate tumor suppressor gene of rhabdoid tumors, the INII gene, showed no mutations or loss of expression in the tumor cells. Although ERRTs typically have an aggressive clinical course, the patient was still alive without any evidence of recurrence or metastasis at 26 months after surgery. The rhabdoid features of the present case seemed to be a variant of gastric adenocarcinoma.
\end{abstract}

Keywords Adenocarcinoma $\cdot$ INII $\cdot$ Rhabdoid

K. Shomori $(\bowtie) \cdot$ T. Shiomi $\cdot$ H. Ito

Division of Organ Pathology, Department of Microbiology

and Pathology, Faculty of Medicine, Tottori University,

86 Nishi-cho, Yonago, Tottori 683-8503, Japan

e-mail: shomori@med.tottori-u.ac.jp

K. Sugamura

Department of Surgery, Yasugi Municipal Hospital,

1931 Hirose, Hirose-cho, Yasugi, Shimane 692-0404, Japan

K. Adachi · E. Nanba

Division of Functional Genomics, Research Center

for Bioscience and Technology, Tottori University,

86 Nishi-cho, Yonago, Tottori 683-8503, Japan

\section{Introduction}

Extrarenal rhabdoid tumor (ERRT) has been described in many sites, including the liver, skin, central nervous system, orbit, mediastinum, peritoneal cavity, and urinary bladder [1-10]. To date, sixteen cases of gastric ERRTs [11-17] have been reported.

Here, we present a rare case of a primary gastric adenocarcinoma showing rhabdoid features.

\section{Case presentation}

An 86-year-old woman who was diagnosed with a left incarcerated obturator hernia underwent radical surgery. During postoperative imaging procedures, a gastric tumor was detected. Endoscopic examination revealed a mass on the posterior wall of the gastric body. Biopsy of the mass revealed a moderately differentiated tubular adenocarcinoma. The patient's history and family history were unremarkable. Laboratory data on admission showed serum levels of carbohydrate antigen (CA) 19-9 and carcinoembryonic antigen (CEA) of $433.9 \mathrm{U} / \mathrm{ml}$ and $4.5 \mathrm{ng} / \mathrm{ml}$, respectively. No tumoral lesion was found in any other organs. About 1 month after the above surgery, the patient underwent en-bloc distal gastrectomy with Billroth-I reconstruction and regional lymph node dissection. After the operation, the serum CA19-9 level was $26.6 \mathrm{U} / \mathrm{ml}$ and CEA was $2.8 \mathrm{ng} / \mathrm{ml}$. The patient was still alive without any evidence of recurrence or metastasis at 26 months after the gastrectomy.

Pathological findings

The tumor was located in the posterior wall of the gastric body. The gross features showed an ulcerating infiltrative 


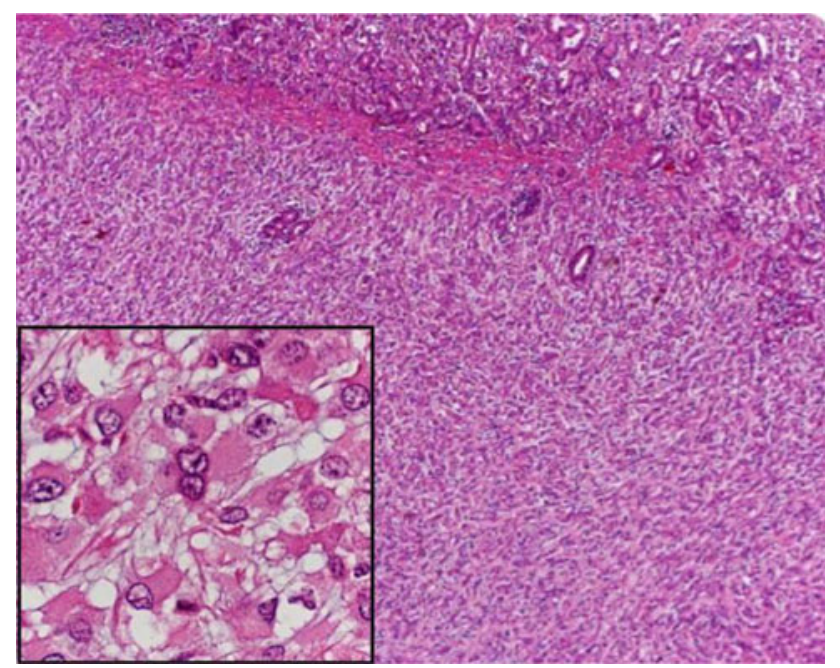

Fig. 1 At low magnification $(\mathrm{H} \& \mathrm{E}, \times 40)$, the gastric tumor mostly shows a solid pattern. The surface portion of the tumor is partially consistent with moderately differentiated tubular adenocarcinoma. At high magnification (inset, $\mathrm{H} \& \mathrm{E}, \times 600$ ), tumor cells in the solid area have vesicular nuclei and abundant eosinophilic cytoplasm. Some cells show rhabdoid features with eccentric nuclei and intracytoplasmic paranuclear inclusions

type that was $5.4 \mathrm{~cm}$ in diameter. The tumor had invaded the subserosal portion of the gastric wall. The tumor cells had grown in a diffuse arrangement, with glandular structures $(<10 \%)$ on the surface of the tumor, corresponding to moderately differentiated tubular adenocarcinoma (H\&E staining; Fig. 1). However, most of the tumor cells were non-cohesive, with a polygonal morphology, showing rhabdoid features, with eccentric vesicular nuclei, prominent nucleoli, and abundant eosinophilic cytoplasm (Fig. 1, inset). Some paranuclear inclusions were also noted in the cytoplasm. There were numerous mitotic figures. We also noted a morphological transition between the two components. The stroma of the tumor was scanty and supported by delicate fibrovascular components. Periodic acid-Schiff staining showed mucin in the glandular tumor cells, but not in the rhabdoid tumor cells. Four of the 21 regional lymph nodes showed metastases that consisted of rhabdoid cells, but not glandular cells.

We next performed immunohistochemical analysis, using antibodies from Dako (Glostrup, Denmark), except for anti-low molecular cytokeratin and INI1 (CAM5.2 and 25/BAF47, respectively), which were from Becton-Dickinson Biosciences (Franklin Lakes, NJ, USA). Antibodies for $\alpha$-fetoprotein (AFP), human chorionic gonadotropin (hCG), c-Kit, S-100 protein, and myoglobin were rabbit polyclonal and the others were mouse monoclonal. The tumor sections were stained immunohistochemically using the streptavidin-biotin-peroxidase complex (SAB) method, as previously described [18]. The immunohistochemical studies showed strong reactivity for pan-cytokeratin (Fig. 2a, left), low-molecular weight cytokeratin (CAM5.2), cytokeratin 7, and epithelial membrane antigen (EMA), with the strongest staining being paranuclear and corresponding to the inclusions shown in the H\&E-stained sections. Immunohistochemistry also showed that the rhabdoid cells were positive for vimentin (Fig. 2a, right) and negative for E-cadherin (Fig. 2b), CEA, and CA19-9. In contrast, cells in the moderately differentiated component were negative for vimentin and positive for E-cadherin (Fig. 2b), CEA, and CA19-9. All of the tumor cells were negative for AFP, hCG, desmin, myoglobin, smooth muscle actin, S-100 protein, CD34, and c-Kit. The rate of Ki-67-positive tumor cells in the glandular and rhabdoid components was 46.4 and $82.8 \%$, respectively (Fig. 2c). We confirmed immunoreactivity for the protein products of the INII gene in the nuclei of rhabdoid cells, carcinomatous cells, and non-tumoral foveolar cells (Fig. 2d). Table 1 summarizes the immunoprofiling of the cancer cells.

\section{Mutation analysis}

We examined whether mutations in the INII gene were present, using DNA extracted from paraffin sections of the tumor, as previously described [19]. We used primer pairs that were previously reported to detect exons 1-9 of the IN11 gene [20]. For exon 8, we constructed an original primer for nested polymerase chain reaction (PCR) $\left(5^{\prime}\right.$ agggcacagacaggggccaaagc $-3^{\prime}$ and $5^{\prime}$-cctgtgggcagagcccag gac- $\left.3^{\prime}\right)$. Each exon extracted from the primary tumor and lymph node metastasis was detected by PCR. The PCR products were directly sequenced and the sequences were compared with those held in the GenBank database (accession no. U04847). However, no mutations were detected (data not shown).

\section{Discussion}

Extrarenal rhabdoid tumors (ERRTs) are exceedingly rare in the stomach, and only 16 cases have been reported to date. These cases, as well as the present case, are summarized in Table 2. Ueyama et al. [11] reported that only four gastric tumors, of 5437 cases of gastric adenocarcinoma, showed rhabdoid features. These tumors consisted of either poorly differentiated or non-cohesive round to polygonal cells, and co-expressed keratins and vimentin [11-13]. The presence of a few glandular structures might suggest an adenocarcinoma cell origin, as in our case. Moreover, immunohistochemical profiling revealed an absence of features that could assign this tumor to a specific category, such as myogenic, neural, glial, or 

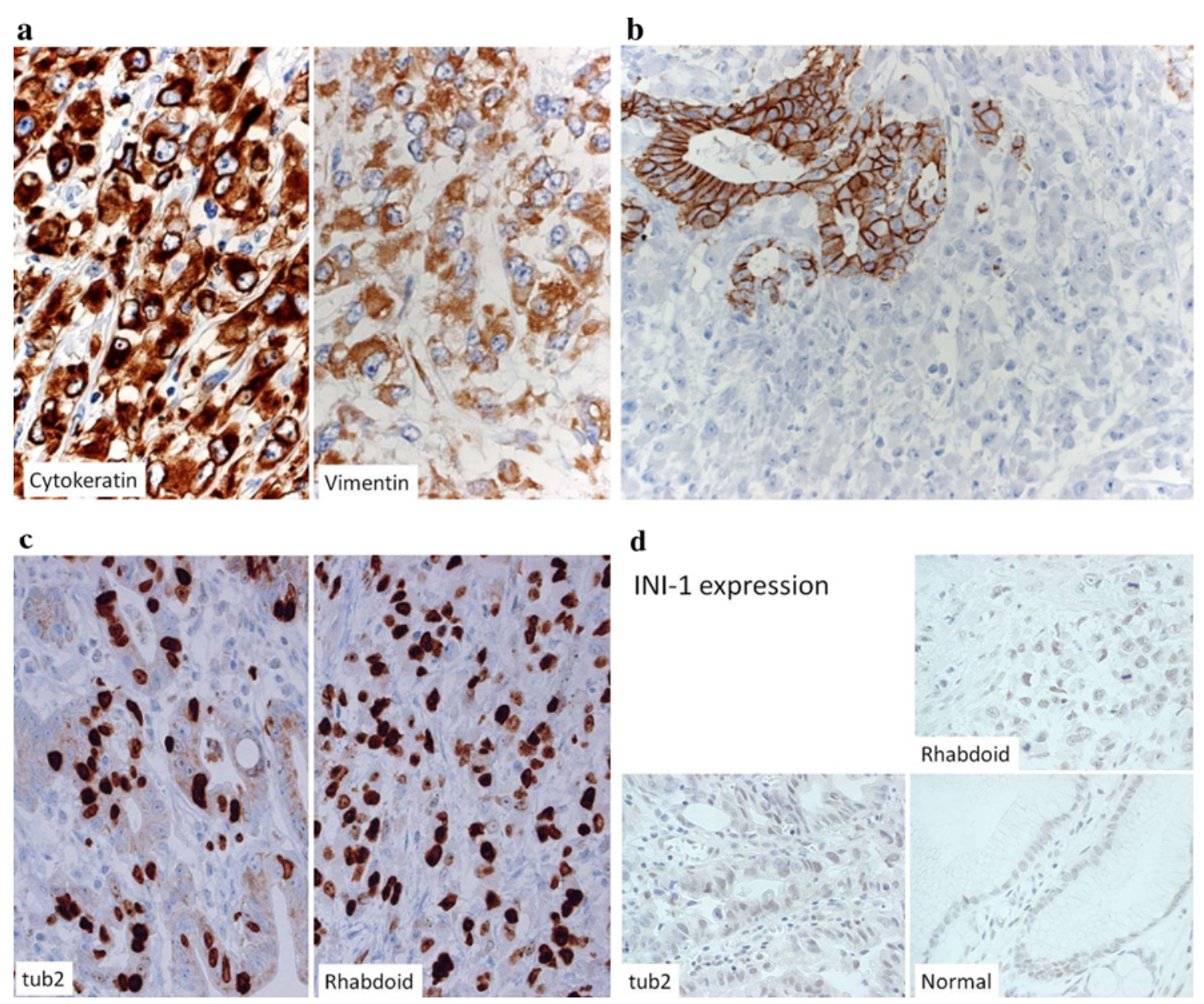

Fig. 2 a The tumor cells show intracytoplasmic immunostaining for cytokeratin (AE1/AE3) (left) and vimentin (right) $(\times 600)$. b E-cadherin is strongly expressed in the glandular components (left) of the tumor, but not in the rhabdoid components (right) $(\times 600)$. c Immunoreactivity for Ki67 in the nucleus of tubular

interstitial cells of Cajal. Additionally, the high Ki-67 labeling index and the loss of E-cadherin expression suggested that the tumor cells had extremely high proliferative potential and had lost the cohesive function of the E-cadherin system.

ERRTs, similar to classical RTs, are very aggressive, with very poor prognoses [1]. It is of note that eight of the above reported seventeen patients died within 6 months after surgery (Table 2). All of these patients were thought to have had distant metastasis at the time of the surgery. In the present patient, metastatic tumors were noted in four of a total of 21 regional lymph nodes, although the patient was still alive with no evidence of recurrence or metastasis 26 months after surgery. Accordingly, it seems that patients with gastric ERRT can be cured by sufficient resection, even if they have lymph node metastasis.

Cytogenetic studies have discovered a mutation of the Hsnf5/INII gene, located on chromosomal band 22q11.2, adenocarcinoma $(t u b 2)$ and rhabdoid cells $(\times 600)$. d Immunoreactivity for INI1 in the nucleus of rhabdoid cells, tubular adenocarcinoma (tub2), and normal foveolar cells $($ Normal $)(\times 600)$. Some stromal cells in each portion are also weakly stained

in renal RT and ERRT [21]. Accordingly, the INII gene seems to be a tumor suppressor involved in both RT and ERRT. In the present case, we found no mutations in the INI gene, and no abnormal protein expression. These findings suggest two possibilities. First, there may have been no mutations of the INI gene in this tumor. Although INI1 protein was recognized by immunohistochemistry, its expression tended to be weaker in the tumor tissue than in the surrounding normal epithelium. Second, because of post-translational changes, such as phosphorylation, the functions of the INI1 protein may have been abnormal. Hoot et al. [22] reported that INII gene mutations were not present in five of 19 RTs and one of eight ERRTs in children. ERRT, in addition to INI gene mutations, might also be caused by the loss of INI protein function or by other, still unknown factors.

Most ERRTs are considered to be biphasic lesions composed of rhabdoid cells and either carcinomatous or 
Table 1 Immunoprofiling of the tumor cells

\begin{tabular}{|c|c|c|c|c|c|c|}
\hline \multirow[t]{2}{*}{ Antibodies } & \multirow[t]{2}{*}{ Clone } & \multirow[t]{2}{*}{ Commercial source } & \multirow[t]{2}{*}{ Dilution } & \multirow[t]{2}{*}{ Antigen retrieval } & \multicolumn{2}{|c|}{ Reactivity of the tumor cells } \\
\hline & & & & & Rhabdoid cells & Glandular cells \\
\hline Vimentin & Vim 3 B4 & DAKO & $1 / 100$ & MW/EDTA & + & - \\
\hline Pan-CK & AE1/AE3 & DAKO & $1 / 100$ & Pro & + & + \\
\hline CK (low molecular) & CAM 5.2 & Becton-Dickinson Biosciences & Diluted & Pro & + & + \\
\hline CK7 & OV-TL12/30 & DAKO & $1 / 100$ & Pro & + & + \\
\hline EMA & E29 & DAKO & $1 / 100$ & Pro & + & + \\
\hline E-cadherin & $\mathrm{NCH}-38$ & DAKO & $1 / 100$ & $\mathrm{MW} / \mathrm{CB}$ & - & + \\
\hline CA 19-9 & 116-NS-19-9 & DAKO & $1 / 50$ & - & - & + \\
\hline CEA & II-7 & DAKO & $1 / 50$ & $\mathrm{MW} / \mathrm{CB}$ & - & + \\
\hline AFP & Poly (rabbit) & DAKO & $1 / 1000$ & - & - & - \\
\hline hCG & Poly (rabbit) & DAKO & $1 / 500$ & - & - & - \\
\hline Desmin & D 33 & DAKO & $1 / 50$ & $\mathrm{MW} / \mathrm{CB}$ & - & - \\
\hline Myoglobin & Poly (rabbit) & DAKO & $1 / 1000$ & - & - & - \\
\hline S-100 protein & Poly (rabbit) & DAKO & $1 / 500$ & $\mathrm{MW} / \mathrm{CB}$ & - & - \\
\hline CD 34 & BI-3C5 & DAKO & $1 / 50$ & $\mathrm{MW} / \mathrm{CB}$ & - & - \\
\hline c Kit & Poly (rabbit) & DAKO & $1 / 100$ & $\mathrm{MW} / \mathrm{CB}$ & - & - \\
\hline Ki67 LI & MIB-1 & DAKO & $1 / 100$ & $\mathrm{MW} / \mathrm{CB}$ & $82.8 \%$ & $46.4 \%$ \\
\hline INI & 25/BAF 47 & Becton-Dickinson Biosciences & $1 / 100$ & $\mathrm{MW} / \mathrm{CB}$ & + & + \\
\hline
\end{tabular}

$C K$ cytokeratin, $C E A$ carcinoembryonic antigen, EDTA ethylenediaminetetraacetic acid, EMA epithelial membrane antigen, $A F P$ alpha-fetoprotein, $h C G$ human chorionic gonadotropin, $L I$ labeling index, $M W$ microwave, Pro protease, $C A$ carbohydrate antigen, $C B$ citrate buffer

Table 2 Clinicopathological findings in the present patient and 16 previously reported patients with gastric adenocarcinoma with rhabdoid features

\begin{tabular}{|c|c|c|c|c|c|c|c|}
\hline \multirow[t]{2}{*}{ Case no. } & \multirow[t]{2}{*}{ Reference } & \multirow[t]{2}{*}{ Age (years)/sex } & \multirow[t]{2}{*}{ Tumor size $(\mathrm{cm})$} & \multirow[t]{2}{*}{ Glandular component } & \multirow[t]{2}{*}{ Metastasis } & \multicolumn{2}{|c|}{ Follow-up (months) } \\
\hline & & & & & & DOD & Alive \\
\hline 1 & {$[11,12]$} & $63 / \mathrm{M}$ & 11 & Present & Liver & 2 & \\
\hline 2 & {$[11,12]$} & $60 / \mathrm{M}$ & 8 & Present & $(-)$ & & 49 \\
\hline 3 & {$[11,12]$} & $68 / \mathrm{M}$ & 3 & Present & $(-)$ & & 60 \\
\hline 4 & {$[11,12]$} & $58 / \mathrm{M}$ & 13 & Present & $(-)$ & 6 & \\
\hline 5 & {$[12]$} & No data & No data & Present & $\mathrm{LN}$ & & 6 \\
\hline 6 & {$[12]$} & No data & No data & Present & $\mathrm{LN}$ & 5 & \\
\hline 7 & {$[12]$} & No data & No data & Present & $\mathrm{LN}$ & No data & \\
\hline 8 & {$[12]$} & No data & No data & Present & $\mathrm{LN}$ & 5 & \\
\hline 9 & [12] & No data & No data & Absent & No data & 29 & \\
\hline 10 & [12] & No data & No data & Absent & $\mathrm{LN}$ & 9 & \\
\hline 11 & [12] & No data & No data & Absent & $(-)$ & 2 & \\
\hline 12 & {$[12]$} & No data & No data & Present & No data & & 36 \\
\hline 13 & [14] & $59 / \mathrm{F}$ & 16 & Absent & Liver, lung & 4 & \\
\hline 14 & [15] & $73 / \mathrm{F}$ & 9 & Present & Umbilical region & 3 & \\
\hline 15 & [16] & $52 / \mathrm{M}$ & 13 & Present & Liver, LN & 4 & \\
\hline 16 & [17] & $40 / \mathrm{F}$ & 12 & No data & No data & No data & \\
\hline 17 & Present patient & $86 / \mathrm{F}$ & 5.4 & Present & $\mathrm{LN}$ & & 26 \\
\hline
\end{tabular}

$L N$ lymph node, DOD dead of disease

mesenchymal cells. Parham et al. [1] have suggested that ERRTs are a heterogeneous group of unrelated tumors with cellular morphology similar to that of renal RTs. Moreover,
Pinto et al. [15] suggested that the rhabdoid areas probably represent a phenotypic variant of gastric adenocarcinoma. Twelve of the seventeen reported cases of gastric ERRT, 
including the present case, exhibited a carcinomatous component (Table 2). The cells with rhabdoid features were positive for vimentin in all 17 cases, and they were positive for cytokeratin or EMA in 16 cases. Although the morphological and immunohistochemical findings for gastric ERRTs are similar to those for renal RT, the findings in our patient support the hypothesis that gastric ERRTs originate from epithelial components.

\section{References}

1. Parham DM, Weeks DA, Beckwith JB, et al. The clinicopathologic spectrum of putative extrarenal rhabdoid tumor: an analysis of 42 cases with immunohistochemical and electron microscopy. Am J Surg Pathol. 1994;18:1010-29.

2. Ogino S, Ro JY, Redline RW. Malignant rhabdoid tumor: a phenotype? An entity? A controversy revisited. Adv Anat Pathol. 2000;7:181-90.

3. Scheimberg I, Cullinane C, Kelsey A, Malone M, et al. Primary hepatic malignant tumor with rhabdoid features. A histological, immunocytochemical, and electron microscopic study of four cases and a review of the literature. Am J Surg Pathol. 1996;20:1394-400.

4. Dabbs DJ, Park HK, et al. Malignant rhabdoid skin tumor: an uncommon primary skin neoplasm Ultrastructural and immunohistochemical analysis. J Cutan Pathol. 1988;15:109-15.

5. Chou SM, Anderson JS, et al. Primary CNS malignant rhabdoid tumor (MRT): report of two cases and review of literature. Clin Neuropathol. 1991;10:1-10.

6. Rootman J, Damji KF, Dimmick JE, et al. Malignant rhabdoid tumor of the orbit. Ophthalmology. 1989;96:1650-4.

7. Falconieri G, Moran CA, Pizzolitto S, Zidar A, Angione V, Jr Wakely PE, et al. Intrathoracic rhabdoid carcinoma: a clinicopathological, immunohistochemical, and ultrastructural study of 6 cases. Ann Diagn Pathol. 2005;9:279-83.

8. Ohgaki M, Higuchi A, Chou H, Takashina K, Kawakami S, Fujita Y, Hagiwara A, Yamagishi $\mathrm{H}$, et al. An extrarenal malignant rhabdoid tumor suspected to originate from the mesentery in an adult: report of a case. Surg Today. 2003;33:556-9.

9. Inagaki T, Nagata M, Kaneko M, Amagai T, Iwakawa M, Watanabe $\mathrm{T}$, et al. Carcinosarcoma with rhabdoid features of the urinary bladder in a 2-year-old girl: possible histogenesis of stem cell origin. Pathol Int. 2000;50:973-8.
10. Wick MR, Ritter JH, Dehner LP, et al. Malignant rhabdoid tumor: a clinicopathological review and conceptual discussion. Semin Diagn Pathol. 1995;12:233-48.

11. Ueyama T, Nagai E, Yao T, Tsuneyoshi M, et al. Vimentinpositive gastric carcinomas with rhabdoid features: a clinicopathologic and immunohistochemical study. Am J Surg Pathol. 1993;17:813-9.

12. Utsunomiya T, Yao T, Masuda K, Tsuneyoshi M, et al. Vimentinpositive adenocarcinomas of the stomach: co-expression of vimentin and cytokeratin. Histopathology. 1996;29:507-16.

13. Utsunomiya T, Yao T, Tamiya S, Tsuneyoshi M, et al. Intracellular distribution of intermediate filaments in vimentin-positive gastric carcinomas: confocal laser scanning microscopy using formalin-fixed paraffin-embedded specimens. Pathol Res Pract. 2002;198:69-76.

14. Read HS, Webb JN, Macintyre IMC, et al. Malignant rhabdoid tumour of stomach. Histopatholgy. 1996;29:474-7.

15. Pinto JA, Gonzalez Alfonso JE, Gonzalez L, Stevenson N, et al. Well differentiated gastric adenocarcinoma with rhabdoid areas: a case report with immunohistochemical analysis. Pathol Res Pract. 1997;193:801-5.

16. Amrikachi M, Ro JY, Ordonez NG, Ayala AG, et al. Adenocarcinomas of the gastrointestinal tract with prominent rhabdoid features. Ann Diagn Pathol. 2002;6:357-63.

17. Sharma S, Gupta R, Sharma R, Kotru M, et al. Mucin-secreting gastric adenocarcinoma with rhabdoid areas. Saudi J Gastroenterol. 2010;16:46-8.

18. Shomori K, Nagashima Y, Kuroda N, Honjo A, Tsukamoto Y, Tokuyasu N, Maeta N, Matsuura K, Hijiya N, Yano S, Yokoyama $\mathrm{S}$, Ito $\mathrm{H}$, Moriyama $\mathrm{M}$, et al. ARPP protein is selectively expressed in renal oncocytoma, but rarely in renal cell carcinomas. Mod Pathol. 2007;20:199-207.

19. Kitamura Y, Nanba E, Inui S, Tanigawa T, Ichihara K. Diagnosis of lymphoma in paraffin wax sections by nested PCR and immunohistochemistry. J Clin Pathol. 1996;49:333-7.

20. Hulsebos TJ, Plomp AS, Wolterman RA, Robanus-Maandag EC, Baas F, Wesseling $P$, et al. Germline mutation of INI1/ SMARCB1 in familial schwannomatosis. Am J Hum Genet. 2007;80:805-10.

21. Biegel JA, Zhou JY, Rorke LB, Stenstrom C, Wainwright LM, Fogelgren B, et al. Germ-line and acquired mutations of INI1 in atypical teratoid and rhabdoid tumors. Cancer Res. 1999;59:74-9.

22. Hoot AC, Russo P, Judkins AR, Perlman EJ, Biegel JA, et al. Immunohistochemical analysis of hSNF5/INI1 distinguishes renal and extra-renal malignant rhabdoid tumors from other pediatric soft tissue tumors. Am J Surg Pathol. 2004;28:1485-91. 